\title{
CATION EXCHANGE CAPACITY OF AN OXISOL AMENDED WITH AN EFFLUENT FROM DOMESTIC SEWAGE TREATMENT
}

\author{
Adriel Ferreira da Fonseca ${ }^{1,2}$; Luís Reynaldo Ferracciú Alleoni ${ }^{3 *}$; Adolpho José Melfi ${ }^{2,3}$; Célia \\ Regina Montes ${ }^{2,3}$ \\ ${ }^{1}$ USP/CENA - Lab. de Ecologia Isotópica - 13400-970 - Piracicaba, SP - Brasil. \\ ${ }^{2}$ USP/ESALQ - Núcleo de Pesquisa em Geoquímica e Geofísica da Litosfera (Nupegel). \\ ${ }^{3}$ USP/ESALQ - Depto. de Solos e Nutrição de Plantas, C.P. 09 - 13418-900 - Piracicaba, SP - Brasil. \\ *Corresponding author <lrfalleo@esalq.usp.br>
}

\begin{abstract}
The addition of Na-rich anthropogenic residues to tropical soils has stimulated the scientific community to study the role of sodium in both the soil solution and the exchange complex. In this study, several different methods were used to calculate the concentration of exchangeable and soluble cations and this data was then used to establish correlations between the level of these cations and both the accumulation of various elements and the dry weight of maize grown in a greenhouse under different conditions. In the closed environments of the pots, the most suitable method for calculating the effective cation exchange capacity (ECEC) was the cation exchange capacity calculated by cations removed with barium chloride solution $\left(\mathrm{CEC}_{\mathrm{S}}\right)$. Then again, the actual cation exchange capacity $\left(\mathrm{CEC}_{\mathrm{A}}\right)$ should be measured by using $\mathrm{Mg}$ adsorption to prevent ionic force from influencing electric charges. A strong positive correlation was obtained between the concentrations of $\mathrm{Na}$ in the 1:2 soil:water extracts and the accumulation of $\mathrm{Na}$ in the maize plants, indicating saline or double acid extractors are not needed when monitoring the Na concentration only. Key words: exchangeable cations, soil solution, soil with variable charge, treated sewage effluent, maize
\end{abstract}

\section{CAPACIDADE DE TROCA CATIÔNICA DE UM LATOSSOLO TRATADO COM EFLUENTE DE TRATAMENTO DE ESGOTO DOMÉSTICO}

\begin{abstract}
RESUMO: A disposição de resíduos antropogênicos ricos em sódio nos solos tropicais tem despertado o interesse da comunidade científica em estudar a participação deste elemento no complexo de troca, bem como na solução no solo. Objetivou-se neste trabalho estabelecer correlações entre as concentrações de cátions trocáveis e de cátions solúveis, obtidos por diferentes métodos, com o acúmulo de elementos e com a massa seca no milho. O experimento foi conduzido em casa de vegetação, sob diferentes condições. Para experimentos em ambiente fechado (vasos), o método mais indicado para o cálculo da capacidade de troca cationnica efetiva $\left(\mathrm{CTC}_{\mathrm{e}}\right)$ é a capacidade de troca catiônica calculada a partir dos cátions removidos com solução de cloreto de bário. Ainda, a capacidade de troca catiônica atual deve ser medida ao $\mathrm{pH}$ do solo pela adsorção de $\mathrm{Mg}$, para evitar a influência da força iônica nas cargas elétricas. Obteve-se alta correlação positiva entre a concentração de $\mathrm{Na}$ no extrato aquoso 1:2 e o acúmulo deste elemento nas plantas, indicando que quando somente o monitoramento do $\mathrm{Na}$ for necessário, pode-se desprezar o uso dos extratores salino ou duplo ácido.

Palavras-chave: cátions trocáveis, solução no solo, solo com carga variável, efluente de esgoto tratado, milho
\end{abstract}

\section{INTRODUCTION}

Stabilization ponds have been extensively used for the treatment of sewage, especially in small and medium sized cities (Feigin et al., 1991). One of the by-products this sewage treatment system is the treated sewage effluent (TSE) - a liquid usually discarded into water-courses, causing environmental problems such as eutrophication, or used to irrigate soil-plant systems. When TSE is added to soil, elements are also added and can alter the effective cation exchange capacity (CEC).
The CEC of a soil can be obtained by various methods. The actual CEC $\left(\mathrm{CEC}_{\mathrm{A}}\right)$ is the quantity of $\mathrm{Mg}$ absorbed by a soil at its native $\mathrm{pH}$ (Gillman, 1979). CEC may also be calculated by sum of $\mathrm{Al}, \mathrm{Ca}, \mathrm{Mg}, \mathrm{K}$, and $\mathrm{Na}$, exchanged by Ba (Gillman, 1979) - $\mathrm{CEC}_{\mathrm{s}}$. The effective cation exchange capacity (ECEC) is indirectly measured, since different extractors are used, such as potassium chloride (for Al), Mehlich-1 solution (Na), and ion-exchange resin $(\mathrm{Ca}, \mathrm{Mg}$, and $\mathrm{K})$. In closed environments, these methods do not always generate the same CEC, because the increased ionic force of the soil solution can 
also increase CEC (Gillman, 1981). CEC calculated for potted soil samples by summing values of exchangeable cations and potential acidity might be also overestimated, because no leaching occurs in the potted soil samples, not all the exchangeable cations may be adsorbed in the soil exchange sites, and part of the cations might be bound to some anions present in the soil solution. When these cations are conventionally extracted (by extracting solution), they are often overestimated (Fonseca et al., 2005b).

Methods for measuring CEC were correlated and both the accumulation of $\mathrm{Ca}, \mathrm{Mg}, \mathrm{K}$ and $\mathrm{Na}$ by maize and maize dry weight were evaluated. It was assumed that (i) the addition of rich-Na effluent increases ionic strength and leads to a mistaken CEC value, mainly in pot experiment; and (ii) weakly adsorbed cations $\left(\mathrm{Na}^{+}\right.$e $\left.\mathrm{K}^{+}\right)$can be extracted by aqueous extracts.

\section{MATERIAL AND METHODS}

The experiment was conducted in a greenhouse. Experimental units consisted of 12.5 -L plastic pot containing $10 \mathrm{~kg}$ of a medium textured Typic Haplustox soil, collected from the $0-20 \mathrm{~cm}$ soil layer in a fallow area in Lins ( $22^{\circ} 21^{\prime} \mathrm{S}, 49^{\circ} 50^{\prime} \mathrm{W}$ ) state of São Paulo, Brazil. An Oxisol, the most representative soil class in humid tropical environments was used. Brazilian surface is essentially lateritic, and close to $60 \%$ of the soils are Oxisols (Chauvel et al., 1983). Before being placed in the pots the soil was air dried, sieved (4-mm screen), and supplemented with the equivalent of $0.94 \mathrm{tha}^{-1}$ of dolomitic lime $(30.8 \% \mathrm{CaO} ; 19.8 \% \mathrm{MgO})$ to bring base saturation up to $65 \%$, the quantity of lime added to each pot being adjusted to take into account soil density $\left(1.37 \mathrm{~kg} \mathrm{~m}^{-3}\right)$, determined using the test tube method (Embrapa, 1997). After liming, the soil samples were thoroughly mixed, placed in pots and maintained for 21 days at circa $70 \%$ of the soil water retention capacity as determined using the soil moisture saturation technique (Embrapa, 1997). Following incubation, the soil was removed from the pots, air-dried, fertilized and re-potted.

Before seeding, the soil was analyzed physically and chemically; analyses showing the following: $\mathrm{pH}=$ 5.2 ; base saturation $=59 \% ; 780 \mathrm{~g} \mathrm{~kg}^{-1}$ of sand; $60 \mathrm{~g} \mathrm{~kg}^{-1}$ of silt; $160 \mathrm{~g} \mathrm{~kg}^{-1}$ of clay; CEC at $\mathrm{pH} 7.0=53.2 \mathrm{mmol}_{\mathrm{c}}$ $\mathrm{kg}^{-1}$; cations $\left(\mathrm{mmol}_{\mathrm{c}} \mathrm{kg}^{-1}\right) \mathrm{Ca}=19.2, \mathrm{Mg}=9.6, \mathrm{~K}=2.1^{\mathrm{c}}$, $\mathrm{Na}=0.4$ and $\mathrm{Al}=0.0$; other elements $\left(\mathrm{mg} \mathrm{kg}^{-1}\right) \mathrm{Fe}=$ 100.0, $\mathrm{S}=28.8, \mathrm{P}=4.1, \mathrm{Mn}=1.1, \mathrm{~B}=0.5, \mathrm{Cu}=0.5$ and $\mathrm{Zn}=0.4$. The pipette method of Kilmer \& Alexander (1949) was used for particle-size analysis. Fractions $<2$ $\mathrm{mm}$ were separated into sand $(2-0.05 \mathrm{~mm})$, silt $(0.05-$ $0.002 \mathrm{~mm})$, and clay $(<0.002 \mathrm{~mm})$. The soil $\mathrm{pH}$ was determined in $0.01 \mathrm{~mol} \mathrm{~L}^{-1} \mathrm{CaCl}_{2}$ solution, using a 1:2.5 (v:v) soil:solution ratio suspension. Exchangeable- $\mathrm{Al}$ and $\mathrm{H}+\mathrm{Al}$ concentrations were determined in soil extracts obtained with a $1 \mathrm{~mol} \mathrm{~L}^{-1} \mathrm{KCl}$ solution and a $0.5 \mathrm{~mol} \mathrm{~L}^{-1}$ calcium acetate-pH 7.0 solution, respectively. The concentrations were determined by titration using a standard $0.025 \mathrm{~mol} \mathrm{~L}^{-1} \mathrm{NaOH}$ solution. Exchangeable-Na concentrations were determined in soil extracts obtained with Mehlich-1 solution, following readings by flame emission photometry (FEP) procedure. Exchangeable $\mathrm{Ca}, \mathrm{Mg}$ and $\mathrm{K}$, and available $\mathrm{P}$ were determined in soil extracts obtained with the ion exchange resin procedure described by Raij et al. (1986), following readings by atomic absorption spectrophotometry (AAS) for $\mathrm{Ca}$ and $\mathrm{Mg}$, and FEP for K, and molecular absorption spectrophotometry for P. Available $\mathrm{S}$ was extracted using a $0.01 \mathrm{~mol} \mathrm{~L}^{-1}$ phosphate monocalcium solution and $\mathrm{S}$ was determined by turbidimetry according to Fox et al. (1987). Available B was extracted with a $0.006 \mathrm{~mol} \mathrm{~L}^{-1}$ barium chloride solution heated in a microwave oven and determined by the Azomethin-H method, according to Abreu et al. (1994). The available concentrations of $\mathrm{Cu}, \mathrm{Fe}$, $\mathrm{Mn}$ and $\mathrm{Zn}$ were determined according to Lindsay \& Norvell (1978), following reading by inductively coupled plasma optical emission spectrometry (ICP-OES). Based on these analytical determinations, the following variables were calculated: $\mathrm{CEC}$ at $\mathrm{pH} 7.0$ $\left(\mathrm{CEC}_{7}=\mathrm{Ca}+\mathrm{Mg}+\mathrm{K}+\mathrm{Na}+\mathrm{H}+\mathrm{Al}\right)$; base-saturation $\left(V=(C a+M g+K+N a) * 100 / C E C_{7}\right)$.

The secondary-treated sewage effluent (STSE; hereafter 'effluent') used in our experiments was collected from the stabilization ponds at the Lins wastewater treatment plant and analyzed according to standard procedures (APHA, 1992) and showed the following characteristics: $\mathrm{pH}=7.7$; electrical conductivity $(\mathrm{EC})=0.84 \mathrm{dS} \mathrm{m}^{-1}$; alkalinity $\left(\right.$ as $\left.\mathrm{CaCO}_{3}\right)=358 \mathrm{mg} \mathrm{L}^{-1}$; sodium adsorption ratio $(\mathrm{SAR})=15.8\left(\mathrm{mmol} \mathrm{L}^{-1}\right)^{0.5}$; principal elements $(\mathrm{mg}$ $\mathrm{L}^{-1}$, in order of magnitude), $\mathrm{Na}$ (134), K (10.9), S (10.2), $\mathrm{P}$ (8.4), $\mathrm{Ca}(8.1), \mathrm{Mg}(1.5)$ and B (0.15); trace elements ( $\left.\mu \mathrm{g} \mathrm{L}^{-1}\right), \mathrm{Fe}$ (143.5), Zn (4.5), Mn (35.5), Pb (3.4), $\mathrm{Cr}$ (2.0), $\mathrm{Cu}$ (1.7), $\mathrm{Ni}(1.0)$ and $\mathrm{Cd}$ (0.05). Analytical methods used were: (i) $\mathrm{pH}$ by potenciometry; (ii) electric conductivity by conductivimetry; (iii) alkalinity (like $\mathrm{CaCO}_{3}$ ) by titration using a standard $0.025 \mathrm{~mol} \mathrm{~L}^{-1}$ sulfuric acid solution; (iv) $\mathrm{S}_{-} \mathrm{SO}_{4}{ }^{2-}$ and $\mathrm{P}-\mathrm{H}_{2} \mathrm{PO}_{4}{ }^{2-}$ by liquid chromatography; (v) $\mathrm{Na}, \mathrm{K}, \mathrm{Ca}, \mathrm{Mg}, \mathrm{B}, \mathrm{Fe}, \mathrm{Zn}$, $\mathrm{Mn}, \mathrm{Pb}, \mathrm{Cr}, \mathrm{Cu}, \mathrm{Ni}$ and $\mathrm{Cd}$ by ICP-OES. Based on these analytical determinations SAR was calculated: $S A R=(\mathrm{Na} / \sqrt{\mathrm{Ca}+\mathrm{Mg}}$ where $\mathrm{Na}, \mathrm{Ca}$ and $\mathrm{Mg}$ were given in $\mathrm{mmol} \mathrm{L}^{-1}$. The collected effluent was stored at $0^{\circ} \mathrm{C}$, effluent for irrigation being equilibrated to room temperature $\left(27.5 \pm 7.8^{\circ} \mathrm{C}\right) 30 \mathrm{~min}$ before use. Additional details are described in Fonseca et al. (2005a).

A randomized complete block experimental design was used, with five treatments $(\mathrm{n}=5)$ : $\mathrm{T} 1=$ irrigation with deionized water and mineral fertilization without nitrogen; T2 = irrigation with deionized water and complete mineral fertilization including nitrogen; $\mathrm{T} 3=$ irrigation with effluent only with no addition of mineral 
fertilizer; T4 $=$ irrigation with effluent and mineral fertilization without nitrogen; T5 = irrigation with effluent and complete mineral fertilization including nitrogen. Effluent treatments were chosen because it is necessary to know the effects of irrigation with Na-rich wastewater in tropical soils, particularly because of the small CEC of those soils. Gillman (1981) stated that the addiction of nitrogen fertilizer to cause increase of ionic strength and, consequently affects CEC. In addition, inclusion of treatments with and without $\mathrm{N}$ was necessary because this nutrient affects greatly the nutrients' uptake and dry matter yield. The concentration of elements remaining in potted soil was distinct. More information can be seen in Fonseca et al. (2005a; 2005b). In all cases, mineral fertilization was done with $300 \mathrm{mg} \mathrm{kg}^{-1}$ of $\mathrm{N}$ (as urea $-45 \%$ $\mathrm{N}$ ), $200 \mathrm{mg} \mathrm{kg}^{-1}$ of $\mathrm{P}$ (as simple-superphosphate - 18\% $\mathrm{P}_{2} \mathrm{O}_{5}$ ), $150 \mathrm{mg} \mathrm{kg}^{-1}$ of $\mathrm{K}$ (as potassium chloride $-60 \%$ $\mathrm{K}_{2} \mathrm{O}$ ), $0.5 \mathrm{~g} \mathrm{~kg}^{-1} \mathrm{~B}$ (as boric acid - 17\% B), $1.5 \mathrm{mg} \mathrm{kg}^{-1} \mathrm{Cu}$ (as cupric sulfate pentahydrate $-25 \% \mathrm{Cu}$ ), $5.0 \mathrm{mg} \mathrm{kg}^{-1} \mathrm{Fe}$ (as iron-EDTA - $5000 \mathrm{mg} \mathrm{kg}^{-1}$ ), $3.0 \mathrm{mg} \mathrm{kg}^{-1} \mathrm{Mn}$ (as manganese chloride tetrahydrate - $28 \% \mathrm{Mn}), 0.1 \mathrm{mg} \mathrm{kg}^{-1} \mathrm{Mo}$ (as molybdic acid - $48 \% \mathrm{Mo}$ ), and $5.0 \mathrm{mg} \mathrm{kg}^{-1} \mathrm{Zn}$ (as zinc sulfate heptahydrate - $22 \% \mathrm{Zn}$ ).

In March, 2001, each pot was sown with 12 seeds of the Zea mays L. single hybrid 'Avant'; five days after sowing the weakest seedlings were removed and four seedlings were left per pot. Micronutrients, $\mathrm{P}$ and $\mathrm{S}$ were applied to the treatments irrigated with deionized water once at sowing; for those treatments involving irrigation with effluent, $1 / 3$ of the $\mathrm{N}$ and $\mathrm{K}$ was added to the effluent at sowing and the remainder at 20 and 40 days after emergence of the seedlings. Plants were irrigated during the experiment to replace water losses by evapotranspiration and to keep the soil at $70 \%$ moisture capacity. The average total volume (L per pot) of irrigation solution (deionized water for T1 and T2, effluent for the rest) applied to each pot was 29.6 for T1, 40.0 for T2, 19.6 for T3, 34.9 for T4, and 42.0 for T5. These volumes were applied from seeding/emergence of the seedlings at day 5 until the maize shoots were harvested at the V4 stage (male inflorescence) 58 days after emergence.

After 58 days, maize plants were cut $1 \mathrm{~cm}$ above the soil; the soil was then removed from the pots, air-dried and crushed to pass a 2-mm screen, and analyzed to determine the concentration of soluble (in aqueous extracts) and exchangeable $\mathrm{Al}, \mathrm{Ca}, \mathrm{Mg}, \mathrm{K}$ and $\mathrm{Na}$. Aqueous extracts of soils were prepared using soil:water ratios of 1:2 and $1: 5(\mathrm{~m} / \mathrm{v})$ according to the method of Rhoades (1996), ICP-OES being used to measure $\mathrm{Al}, \mathrm{Ca}, \mathrm{Mg}$ and $\mathrm{K}$ and FEP to measure Na. The ECEC was either measured or calculated using the methods described ahead.

Method 1 estimated the ECEC by the regional standard method (RSM), in which exchangeable Al is extracted with $1 \mathrm{~mol} \mathrm{~L}^{-1} \mathrm{KCl}$ solution and the $\mathrm{Al}$ content determined by titration using $0.025 \mathrm{~mol} \mathrm{~L}^{-1} \mathrm{NaOH}$ solution. Exchangeable $\mathrm{Na}$ is then extracted with the doubleacid Mehlich-1 solution and the $\mathrm{Na}$ content determined by FEP. In this method, exchangeable $\mathrm{Ca}, \mathrm{Mg}$, and $\mathrm{K}$, are extracted using an ion-exchange resin according to the method of Raij et al. (1986). The regional standard method includes the most widespread methods in São Paulo State (Brazil) to test exchangeable $\mathrm{Al}, \mathrm{Ca}, \mathrm{Mg}, \mathrm{K}$, and $\mathrm{Na}$, and the combined ECEC is calculated as the sum of the cations ( $\mathrm{Al}, \mathrm{Ca}, \mathrm{Mg}, \mathrm{K}$, and $\mathrm{Na}$ ).

Method 2 estimated the ECEC using the CEC obtained by sum of the compulsive exchange of $\mathrm{Al}, \mathrm{Ca}, \mathrm{Mg}$, $\mathrm{K}$, and $\mathrm{Na}$, for $\mathrm{Ba}$ (Gillman, 1979). In this method, exchangeable cations are removed with $0.1 \mathrm{~mol} \mathrm{~L}^{-1} \mathrm{BaCl}_{2}$ solution by centrifugation for two hours and the concentration of the ions determined by ICP-OES. The ECEC value being equal to the sum of cations and hence represents the $\mathrm{CEC}_{\mathrm{S}}$.

Method 3 measured the ECEC using the technique described by Gillman (1979), in which exchangeable cations are removed with $0.1 \mathrm{~mol} \mathrm{~L}^{-1}$ aqueous $\mathrm{BaCl}_{2}$ (q.v. Method 2) and the soil washed three times with $0.002 \mathrm{~mol} \mathrm{~L}^{-1}$ aqueous $\mathrm{BaCl}_{2}$ solution, the $\mathrm{CEC}$ being measured at soil $\mathrm{pH}$ by the adsorption of $\mathrm{Mg}$ from a 0.005 mol L-1 solution of $\mathrm{MgSO}_{4}$ with the EC adjusted to 0.300 $\mathrm{dS} \mathrm{m} \mathrm{m}^{-1}$ by the addition of deionized water. The concentration of $\mathrm{Mg}$ in the supernatant solution is determined by AAS and the CEC calculated, and hence represents the actual $\mathrm{CEC}\left(\mathrm{CEC}_{\mathrm{A}}\right)$.

The harvested V4-stage maize plants were separated into leaves and culms, rinsed in deionized water, dried to constant mass in a forced-air oven $\left(60^{\circ} \mathrm{C}\right)$ and weighed before being separately ground in a Wiley mill to pass a $0.75 \mathrm{~mm}$ screen, and stored in small-capped plastic vials. Chemical analysis of the ground tissue was performed according to the methods described by Malavolta et al. (1997) in which the tissue was subjected to mixed nitric/perchloric acid digestion, $\mathrm{Ca}$ and $\mathrm{Mg}$ being determined by AAS and $\mathrm{K}$ and $\mathrm{Na}$ by FEP. The total content of $\mathrm{Ca}, \mathrm{Mg}, \mathrm{K}$ and $\mathrm{Na}$ was expressed as a function of the dry matter yield of the maize leaves and culms.

The statistical analyses were done by using the SAS software Version 8.02 (SAS System, 1999). Data submitted to analyses of variance were: (i) exchangeable $\mathrm{Al}, \mathrm{Ca}, \mathrm{Mg}, \mathrm{K}$, and $\mathrm{Na}$ obtained by regional standard methods and compulsive exchange method; (ii) ECEC calculated using the RSM and the compulsive exchange method, and $\mathrm{CEC}_{\mathrm{A}}$; (iii) accumulation of $\mathrm{Ca}, \mathrm{Mg}, \mathrm{K}$, and $\mathrm{Na}$ in maize plants (leaves + culms). A randomized complete blocks model with five treatments (T1, T2, T3, T4 and T5) and five replications (e.g., five blocks) was used. Treatments means were compared by Tukey test $(\alpha=0.05)$. Simple linear correlations (Pearson correla- 
tion) at minimal $5 \%$ were obtained for the methods 1,2 and 3, and for the aqueous extract results versus the dry matter yield and $\mathrm{Ca}, \mathrm{Mg}, \mathrm{K}$ and $\mathrm{Na}$ accumulation in maize.

\section{RESULTS AND DISCUSSION}

The total dry matter yield ( $\mathrm{g}$ per pot) of maize plants for the different treatments were 55.2 for T1, 128.7 for T2, 23.1 for T3, 90.0 for T4, and 142.6 for T5. Plants irrigated with effluent only (T3) showed the lowest accumulation of elements (Figure 1), because they received no added mineral fertilizer. When complete mineral fertilizer (including nitrogen) was present, irrigation with effluent (T5) resulted in less $\mathrm{Ca}$ and more $\mathrm{K}$ and $\mathrm{Na}$ being accumulated in the maize plants than when deionized water was used for irrigation (T2), but omission of nitrogen from the fertilizer irrigation with effluent (T4) resulted in higher accumulation of $\mathrm{Mg}, \mathrm{K}$ and $\mathrm{Na}$ in the maize than when irrigation was done was with deionized water (T1) (Figure 1). Because the effluent was rich in $\mathrm{Na}$, there was a greater accumulation of this element in plants irrigated with effluent (T3, T4 and T5) than in plants irrigated with deionized water (T1 and $\mathrm{T} 2)$. In all treatments $\mathrm{K}$ accumulated more than $\mathrm{Ca}, \mathrm{Mg}$ and $\mathrm{Na}$ (Figure 1); this agrees with the results found in other published studies which report that maize absorbs much more $\mathrm{K}$ as compared to other cationic elements (Fageria et al., 1997).

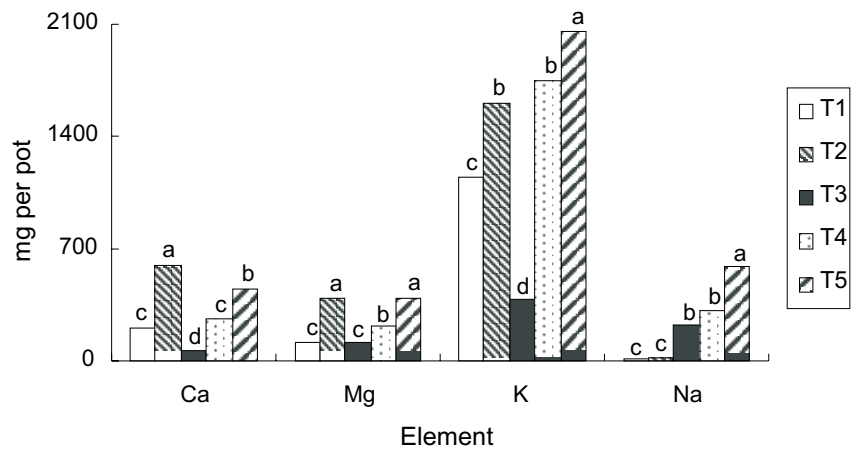

Figure 1 - The accumulation of $\mathrm{Ca}$ (coefficient of variation $(\mathrm{CV})=$ 9.8\%), $\mathrm{Mg}(\mathrm{CV}=12.0 \%), \mathrm{K}(\mathrm{CV}=9.4 \%)$ and $\mathrm{Na}(\mathrm{CV}=$ $23.3 \%)$ in maize plants following irrigation with deionized water or secondary-treated sewage effluent and treatment with mineral fertilizer. Key: $\mathrm{T} 1=$ irrigation with deionized water and mineral fertilization without nitrogen; T2 = irrigation with deionized water and complete mineral fertilization including nitrogen; $\mathrm{T} 3=$ irrigation with effluent only with no addition of mineral fertilizer; T4 = irrigation with effluent and mineral fertilization without nitrogen; T5 = irrigation with effluent and complete mineral fertilization including nitrogen. Data with the same superscript letter do not differ by the Tukey test $(\alpha=0.05)$.
Independent of the extraction method used, higher concentrations of exchangeable $\mathrm{Al}$ were found in the soil in which the $\mathrm{pH}$ was lower (T1 and T2, where $\mathrm{pH}$ was 4.8 and 4.5 , respectively) than in the other treatments (T3, T4 and $\mathrm{T} 5$, where $\mathrm{pH}$ was 5.2, 5.4 and 5.0, respectively). It is known that a decrease of one $\mathrm{pH}$ unit results in a 42-fold increase in $\mathrm{Al}^{3+}$ activity while this increase is 1000 -fold if $\mathrm{Al}^{3+}$ is in equilibrium with amorphous $\mathrm{Al}(\mathrm{OH})_{3}$ or with $\mathrm{Al}$ oxides and hydroxides (Lindsay, 1979). The large variation in aluminum activity caused by small fluctuations in the order of $\pm 0.1 \mathrm{pH}$ units may explain the large coefficient of variation $(\mathrm{CV})$ shown in Table 1. Although the effects of the treatments on the concentrations of exchangeable $\mathrm{Al}$ obtained by solution with $\mathrm{KCl}$ in the $\mathrm{RSM}$ and $\mathrm{BaCl}_{2}$ in the compulsive exchange method were the same, $\mathrm{KCl}$ extracted more $\mathrm{Al}$ in most cases (Table 1). It is known that in some soils, $\mathrm{KCl}$ extracts more $\mathrm{Al}$ than does $\mathrm{BaCl}_{2}$ because the $\mathrm{Al}$ occupying exchange sites is not always entirely removed with $\mathrm{BaCl}_{2}$ (Gillman \& Sumpter, 1986).

With the exception of K, all other exchangeable cations presented lower CV values when the compulsive exchange method was used (Table 1), which may have been due to the greater substitution force of $\mathrm{Ba}$ in compulsive exchange (Curtin et al., 1987), which resulted in more precise results. Independent of the method of extraction, lower concentrations of exchangeable Ca were observed for the T3 group (Table 1), probably because this group received no mineral fertilizer, especially simple superphosphate containing $\mathrm{Ca}, \mathrm{P}$ and $\mathrm{S}$. Larger differences between the treatments were obtained when the compulsive exchange method was used, although there was no correlation with $\mathrm{Ca}$ accumulation in the maize plants (Table 2). Although the compulsive exchange method is generally considered to be the most precise technique, better correlations were observed between dry matter yield and $\mathrm{Ca}$ content of the plants with the quantity of $\mathrm{Ca}$ extracted from the soils by cation exchange resin (RSM, Table 2). This results from the way cation exchange resin works by gradually extracting elements in solution during the extraction process, thus simulating the way in which the roots of plants act (Raij et al., 1986).

Both RSM and compulsive exchange methods indicated that there were higher concentrations of exchangeable $\mathrm{Mg}$ in the T3 group, which received no mineral fertilizer (Table 1), and that the plants in this group grew less and produced less dry matter yield and showed a lower accumulation of cations (Figure 1). The lower accumulation of $\mathrm{Mg}$ in the plants implies that more remained in the soil, thus explaining the negative correlation coefficients between the concentration of exchangeable $\mathrm{Mg}$ and the accumulation this cation and dry matter yield (Table 2). 
Table 1 - Effects of irrigation with deionized water or effluent and mineral fertilization on exchangeable cation concentrations and the effective cation exchange capacity (ECEC) as calculated using the regional standard method and the compulsive exchange method compared with the actual cation exchange capacity $\left(\mathrm{CEC}_{\mathrm{A}}\right)$.

\begin{tabular}{|c|c|c|c|c|c|c|c|}
\hline \multirow[b]{2}{*}{ Treatment } & \multicolumn{5}{|c|}{ Element $\left(\mathrm{mmol}_{\mathrm{c}} \mathrm{kg}^{-1}\right)$} & \multicolumn{2}{|c|}{$\operatorname{ECEC~}\left(\mathrm{mmol}_{\mathrm{c}} \mathrm{kg}^{-1}\right)$} \\
\hline & $\mathrm{Al}$ & $\mathrm{Ca}$ & $\mathrm{Mg}$ & $\mathrm{K}$ & $\mathrm{Na}$ & calculated* & measured $* *$ \\
\hline \multicolumn{8}{|c|}{ Regional standard method } \\
\hline $\mathrm{T} 1$ & $1.8^{\mathrm{a}}$ & $17.6^{\mathrm{a}}$ & $2.0^{b}$ & $0.8^{a}$ & $0.4^{\mathrm{c}}$ & $22.6^{\mathrm{c}}$ & - \\
\hline $\mathrm{T} 2$ & $2.4^{\mathrm{a}}$ & $20.2^{\text {a }}$ & $1.6^{\mathrm{b}}$ & $0.6^{\mathrm{ab}}$ & $0.5^{\mathrm{c}}$ & $25.3^{\mathrm{bc}}$ & - \\
\hline $\mathrm{T} 3$ & $0.0^{\mathrm{b}}$ & $7.2^{\mathrm{b}}$ & $4.2^{\mathrm{a}}$ & $0.4^{\mathrm{b}}$ & $7.3^{b}$ & $19.1^{\mathrm{c}}$ & - \\
\hline $\mathrm{T} 4$ & $0.0^{\mathrm{b}}$ & $21.0^{\text {a }}$ & $2.0^{b}$ & $0.7^{a b}$ & $9.1^{\text {a }}$ & $32.8^{a b}$ & - \\
\hline $\mathrm{T} 5$ & $0.2^{\mathrm{b}}$ & $21.6^{\mathrm{a}}$ & $1.2^{\mathrm{b}}$ & $0.6^{\mathrm{ab}}$ & $10.2^{\mathrm{a}}$ & $33.8^{\text {a }}$ & - \\
\hline $\mathrm{CV}(\%)$ & 60.7 & 20.3 & 33.7 & 27.1 & 12.2 & 14.6 & - \\
\hline \multicolumn{8}{|c|}{ Compulsive exchange method } \\
\hline $\mathrm{T} 1$ & $0.7^{\mathrm{a}}$ & 18.4 bc & $1.6^{\mathrm{b}}$ & $1.0^{\text {a }}$ & $1.0^{\mathrm{d}}$ & $22.7^{b}$ & $23.3^{b}$ \\
\hline $\mathrm{T} 2$ & $1.2^{\mathrm{a}}$ & $16.7^{\mathrm{c}}$ & $1.1^{\mathrm{b}}$ & $0.5^{b}$ & $1.4^{\mathrm{d}}$ & $20.9^{b}$ & $22.5^{b}$ \\
\hline $\mathrm{T} 3$ & $0.1^{\mathrm{b}}$ & $10.0^{\mathrm{d}}$ & $5.8^{a}$ & $0.3^{\mathrm{b}}$ & $7.9^{\mathrm{c}}$ & $24.1^{\mathrm{b}}$ & $24.5^{b}$ \\
\hline $\mathrm{T} 4$ & $0.1^{\mathrm{b}}$ & $22.5^{\text {a }}$ & $1.7^{\mathrm{b}}$ & $0.6^{\mathrm{b}}$ & $9.8^{\mathrm{b}}$ & $34.7^{\text {a }}$ & $27.0^{\text {a }}$ \\
\hline T5 & $0.1^{\mathrm{b}}$ & $22.2^{a b}$ & $1.9^{\mathrm{b}}$ & $0.6^{\mathrm{b}}$ & $11.4^{\mathrm{a}}$ & $36.2^{\text {a }}$ & $27.2^{\text {a }}$ \\
\hline CV $(\%)$ & 56.7 & 11.2 & 26.0 & 35.0 & 11.7 & 6.3 & 4.8 \\
\hline
\end{tabular}

*Calculated ECEC value $=$ sum of cations $(\mathrm{Al}, \mathrm{Ca}, \mathrm{Mg}, \mathrm{K}$ and $\mathrm{Na}) . * *$ Measured ECEC value $=\mathrm{CEC}_{\mathrm{A}}$. Key: $\mathrm{T} 1=$ irrigation with deionized water and mineral fertilization without nitrogen; T2 = irrigation with deionized water and complete mineral fertilizer with nitrogen; T3 = irrigation with effluent only without addition of mineral fertilizer; T4 = irrigation with effluent and mineral fertilizer without nitrogen; T5 = irrigation with effluent and complete mineral fertilizer with nitrogen. For each method, values in the same column with the same subscript do not differ by the Tukey test at $(\alpha=0.05)$. CV $=$ coefficient of variation.

Table 2 - Correlation coefficients for soil exchangeable and soluble cations with maize dry matter yield and the accumulation of $\mathrm{Ca}, \mathrm{Mg}, \mathrm{K}$ and $\mathrm{Na}$ (mg per pot) in maize plants.

\begin{tabular}{|c|c|c|c|c|}
\hline \multirow{3}{*}{$\begin{array}{l}\text { Maize plant } \\
\text { parameters }\end{array}$} & \multicolumn{4}{|c|}{ Correlation coefficients } \\
\hline & \multicolumn{2}{|c|}{ Exchangeable cations } & \multicolumn{2}{|c|}{ Soluble cations } \\
\hline & $\begin{array}{c}\text { Regional standard } \\
\text { method }\end{array}$ & $\begin{array}{c}\text { Compulsive exchange } \\
\text { method }\end{array}$ & $1: 2 \mathrm{soil} /$ water ratio & $1: 5 \mathrm{soil} /$ water ratio \\
\hline $\mathrm{Ca}$ accumulated & $0.64^{* *}$ & $0.38^{\mathrm{NS}}$ & $0.74^{* *}$ & $0.67^{* *}$ \\
\hline Dry matter yield & $0.75^{* *}$ & $0.61^{* *}$ & $0.53^{* *}$ & $0.49^{*}$ \\
\hline $\mathrm{Mg}$ accumulated & $-0.58^{* *}$ & $-0.53^{* *}$ & $0.23^{\mathrm{NS}}$ & $-0.24^{\mathrm{NS}}$ \\
\hline Dry matter yield & $-0.74^{* *}$ & $-0.70^{* *}$ & $0.29^{\mathrm{NS}}$ & $-0.26^{\mathrm{NS}}$ \\
\hline K accumulated & $0.33^{\mathrm{NS}}$ & $0.19^{\mathrm{NS}}$ & $0.35^{\mathrm{NS}}$ & $0.10^{\mathrm{NS}}$ \\
\hline Dry matter yield & $0.13^{\mathrm{NS}}$ & $0.01^{\mathrm{NS}}$ & $0.25^{\mathrm{NS}}$ & $-0.13^{\mathrm{NS}}$ \\
\hline $\mathrm{Na}$ accumulated & $0.90^{* *}$ & $0.92^{* *}$ & $0.94^{* *}$ & $0.93^{* *}$ \\
\hline Dry matter yield & $0.13^{\mathrm{NS}}$ & $0.17^{\mathrm{NS}}$ & $0.42^{*}$ & $0.46^{*}$ \\
\hline
\end{tabular}

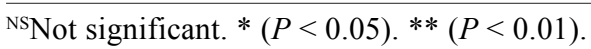

Nearly all of the applied K was absorbed and accumulated in the aerial part of the maize (Figure 1). Because the soil used in the experiments had low CEC, trials were conducted in closed systems and used a highlysoluble K source (KCl) (Lindsay, 1979). Then, it left little potassium in the soil, a fact which contributed to the high $\mathrm{CV}$ values shown in Table 1.

The compulsive exchange method extracted more $\mathrm{Na}$ than the SRM, even though the effects observed for the different treatments were similar for both methods (Table 1). Irrigation with the Na-rich effluent (T3, T4 and T5) resulted in a increasing exchangeable $\mathrm{Na}$ (Table 1) in the soils and the accumulation of this element in the plant tissue (Figure 1). Both RSM and compulsive exchange method were sensitive to variation in exchangeable $\mathrm{Na}$, and so these methods correlated well with the accumulation of $\mathrm{Na}$ in the maize tissue (Table 2). Because it is a bivalent ion, $\mathrm{Ba}$ can extract large amounts of $\mathrm{Na}$. 
Amacher et al. (1990) studied cation exchange methods and found that $\mathrm{Ba}$ extracted more $\mathrm{Na}$ when this last element occurred in concentrations smaller than $2.0 \mathrm{mmol}$ $\mathrm{kg}^{-1}$. This study supports these findings because compared with Mehlich-1 solution, Ba extracted more $\mathrm{Na}$ from the groups (T1 and $\mathrm{T} 2$ ) which had the lowest levels of exchangeable $\mathrm{Na}$, while in the groups with high levels of $\mathrm{Na}$ (T3, T4 and T5), Mehlich-1 solution and $\mathrm{BaCl}_{2}$ extracted almost the same amounts of $\mathrm{Na}$ (Table 1).

A positive correlation $(r>0.70)$ occurred between $\mathrm{Ca}, \mathrm{Mg}, \mathrm{K}$ and $\mathrm{Na}$ levels extracted by the RSM and the compulsive exchange method (Table 3 ), whereas a low correlation $(\mathrm{r}<0.70)$ was observed between such levels and the levels of these elements obtained by aqueous extracts of soils with a soil:water ratio of 1:2 and 1:5 (Table $3)$. When aqueous extracts are made, errors introduced by pipeting, hydrolysis, cation exchange, and dissolution can be high (Sonneveld et al., 1990; Rhoades, 1996) because such extracts are obtained using fine air-dried soil, and it is also known that drying and re-humidification of soils affect the quality of the soil solution because such processes influence the chemical and biological processes which occur in soils (Wolt, 1994). The time needed for total $\mathrm{Ca}, \mathrm{Mg}$ and $\mathrm{K}$ to reach equilibrium in re-hydrated soils is also different and there is an increase in proton donation from highly polarized water molecules associated with the surface of air-dried clays which in dry soils contributes to increased acidity of such surfaces and raised levels of water-soluble organic acids. Such alterations in soil acidity, associated with desiccation and the oxidation of organic material, can alter the available pools of anions and cations by liberating them from soil microflora thus altering not only ion exchange capacity but also affecting reduction reactions (Wolt, 1994).

In this work, soluble $\mathrm{Na}$ in the 1:2 and 1:5 soil:water extracts correlated well with both $\mathrm{Na}$ accumulation in maize tissue and the quantity of $\mathrm{Na}$ extracted by $\mathrm{BaCl}_{2}$ solution (compulsive exchange method) and Mehlich-1 solution (SRM) (Table 2). Therefore, it seems that when it is necessary to monitor only $\mathrm{Na}$ in highly-

Table 3 - Correlation coefficients between exchangeable and the soluble cations obtained by different methods.

\begin{tabular}{|c|c|c|c|}
\hline \multicolumn{2}{|c|}{ Cation extracted by } & \multirow[b]{2}{*}{$\begin{array}{l}\text { 1:2 soil:water } \\
\text { ratio (aqueous } \\
\text { extract) }\end{array}$} & \multirow[b]{2}{*}{$\begin{array}{c}\text { 1:5 soil:water } \\
\text { ratio (aqueous } \\
\text { extract) }\end{array}$} \\
\hline $\begin{array}{l}\text { Regional } \\
\text { standard } \\
\text { method }^{\dagger}\end{array}$ & $\begin{array}{c}\text { Compulsive } \\
\text { exchange } \\
\text { method }\end{array}$ & & \\
\hline $\mathrm{Ca}$ & $0.73^{* *}$ & $0.47^{*}$ & $0.49^{*}$ \\
\hline $\mathrm{Mg}$ & $0.84^{* *}$ & $-0.21^{\mathrm{NS}}$ & $0.39^{\mathrm{NS}}$ \\
\hline K & $0.81^{* *}$ & $0.57^{* *}$ & $0.23^{\mathrm{NS}}$ \\
\hline $\mathrm{Na}$ & $0.99^{* *}$ & $0.93^{* *}$ & $0.91^{* *}$ \\
\hline
\end{tabular}

Reference method. NS: Not significant. ${ }^{*}(P<0.05) .{ }^{* *}(P<0.01)$. weathered soils, values obtained by aqueous extraction using a 1:2 or 1:5 soil:water ratios are as reliable as those obtained using Mehlich-1 solution. Aqueous extraction using a soil:water ratio of $1: 2$, instead of a saturated paste, to investigate the chemical characteristics of soil solutions has been used successfully in Holland (Sonneveld et al., 1990). Although the concentration of soluble $K$ in the $1: 2$ soil:water extract correlated with resin-extracted exchangeable K (RSM, Table 3), there was no correlation either with the accumulation of this element in maize tissue or with maize dry matter (Table 2), this certainly due to the low levels of remaining $\mathrm{K}$ in soils in which maize is planted. Maize plants absorb and accumulate all the $\mathrm{K}$ added by mineral fertilization (Figure 1).

The ECEC as calculated by the $\mathrm{CEC}_{\mathrm{S}}$ (compulsive exchange method) had lower $\mathrm{CV}$ as compared to the ECEC calculated by the RSM (Table 1) because the RSM combines three extraction procedures in which exchangeable $\mathrm{Ca}, \mathrm{Mg}$ and $\mathrm{K}$ are extracted using ion-exchange resin while exchangeable $\mathrm{Al}$ is extracted with $\mathrm{KCl}$ and exchangeable Na with Mehlich-1 solution. This means that RSM is more subject to analytical errors than is the compulsive exchange method, because in the latter case exchangeable cations are extracted with $\mathrm{BaCl}_{2}$ solution only. Amacher et al. (1990) having pointed out that it is desirable to use methods which permit the simultaneous extraction of all exchangeable cations.

Even though the ECEC calculated using the levels of exchangeable cations extracted using the RSM were numerically different to the $\mathrm{CEC}_{\mathrm{S}}$ values, the correlation ( $\mathrm{r}=0.71 ; P<0.01)$ between these methods was positive and highly significant. There was also a correlation between the ECEC calculated using the RSM and the $\mathrm{CEC}_{\mathrm{A}}$ (Figure 2).

The increase in the levels of exchangeable cations, especially exchangeable $\mathrm{Na}$, would certainly result in an overestimate of the ECEC and it appears that for closed environments (i.e. experiments in pots) the compulsive exchange method is better than the regional standard method. The method proposed by Gillman (1979), Method 3, seems to avoid overestimating the ECEC because this method permits the measurement of the cation exchange capacity at the actual $\mathrm{pH}$ of the soil.

\section{CONCLUSIONS}

The problem associated with overestimation of CEC can be solved by removing exchangeable cations with $0.002 \mathrm{~mol} \mathrm{~L}^{-1}$ aqueous $\mathrm{BaCl}_{2}$ solution, and measuring $\mathrm{CEC}$ at soil $\mathrm{pH}$, by the adsorption of $\mathrm{Mg}$ from a 0.005 mol L ${ }^{-1}$ solution of $\mathrm{MgSO}_{4}$ with electrical conductivity adjusted to $0.300 \mathrm{dS} \mathrm{m}^{-1}$, using method described by Gilman (1979). It is possible to obtain satisfactory results of exchangeable cation concentrations through simultaneous extraction with $0.1 \mathrm{~mol} \mathrm{~L}^{-1} \mathrm{BaCl}_{2}$ solution by cen- 


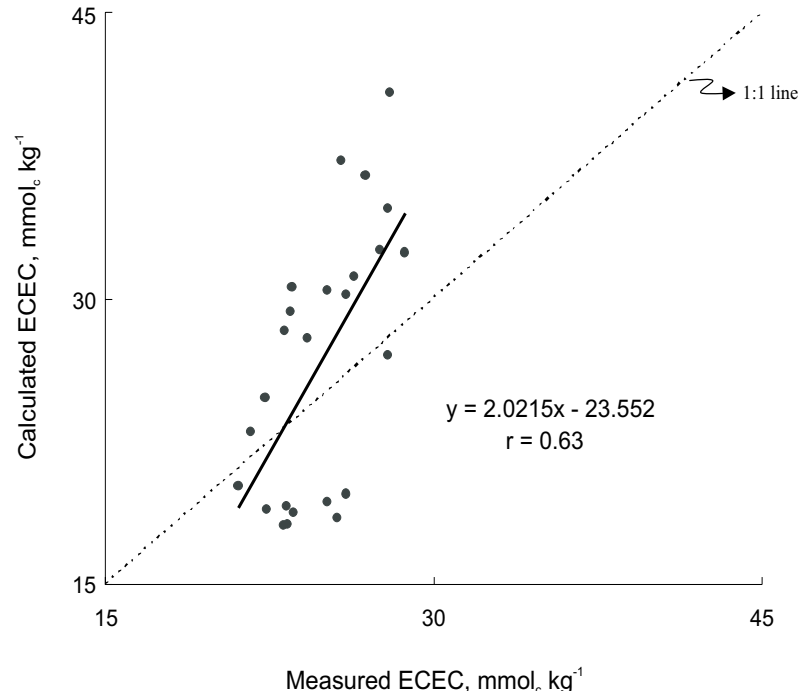

Figure 2 - Correlation between the calculated and the measured effective cation exchange capacity (ECEC). The calculated ECEC was estimated from the sum of the cations ( $\mathrm{Al}, \mathrm{Na}, \mathrm{Ca}, \mathrm{Mg}$ and $\mathrm{K}$ ) as obtained by the regional standard method (RSM). The measured ECEC at soil $\mathrm{pH}$ was obtained by the adsorption of $\mathrm{Mg}$ from a $0.005 \mathrm{~mol} \mathrm{~L}^{-1}$ aqueous solution of $\mathrm{MgSO}_{4}$ and with the electrical conductivity adjusted to $0.300 \mathrm{dS} \mathrm{m}^{-1}$ by the addition of deionized water. ${ }^{* *}$ Significant at $(P<0.01)$

trifugation for two hours and determine those concentrations by ICP-OES. Again, aqueous extracts is not satisfactory for obtaining cations bioavailability, except for $\mathrm{Na}$.

\section{ACKNOWLEDGMENTS}

To Fundação de Amparo à Pesquisa do Estado de São Paulo (FAPESP) for granting fellowship to the first author and financial support for this research. Thanks are also due to Vagner Vidal de Almeida and Carlo Gamper Cardinali, for helping with chemical analysis.

\section{REFERENCES}

ABREU, C.A.; ABREU, M.F.; RAIJ, B. van; BATAGLIA, O.C.; ANDRADE, J.C. Extraction of boron from soil by microwave heating for ICP-AES determination. Communications in Soil Science and Plant Analysis, v.25, p.3321-3333, 1994.

AMACHER, M.C.; HENDERSON, R.E.; BREITHAUPT, M.D.; SEALE, C.L.; LABAUVE, J.M. Unbuffered and buffered salt methods for exchangeable cations and effective cation-exchange capacity. Soil Science Society of America Journal, v. 54, p.1036-1042, 1990.

AMERICAN PUBLIC HEALTH ASSOCIATION. Standard methods for the examination for water and wastewater. 18.ed. Washington: APHA, 1992. 70p.

CHAUVEL, A.; SOUBLES, F.; MELFI, A.J. Ferralitic soils from Brazil: formation and evolution of structure. Sciences Géologiques Mémoire, v.72, p.37-46, 1983.
CURTIN, D.; HUANG, P.M.; ROSTAD, H.P.W. Components and particle size distribution of soil titratable acidity. Soil Science Society of America Journal, v.51, p.332-336, 1987.

EMPRESA BRASILEIRA DE PESQUISA AGROPECUÁRIA. Manual de métodos de análise de solo. 2 .ed. Rio de Janeiro: EMBRAPA, CNPS, 1997. $212 p$

FAGERIA, N.K.; BALIGAR, V.C.; JONES, C.A. Growth and mineral nutrition of field crops. 2.ed. New York: Marcel Dekker, 1997. 624p.

FEIGIN, A.; RAVINA, I.; SHALHEVET, J. Irrigation with treated sewage effluent: management for environmental protection. Berlin: SpringerVerlag, 1991. 224p.

FONSECA, A.F.; MELFI, A.J.; MONTES, C.R. Maize growth and changes in soil fertility after irrigation with treated sewage effluent. I. Plant dry matter yield and soil nitrogen and phosphorus availability. Communications in Soil Science and Plant Analysis, v.36, p.19651981, 2005a.

FONSECA, A.F.; MELFI, A.J.; MONTES, C.R. Maize growth and changes in soil fertility after irrigation with treated sewage effluent. II. Soil acidity, exchangeable cations, and sulfur, boron and heavy metals availability. Communications in Soil Science and Plant Analysis, v.36, p.19832003, 2005b.

FOX, R.L.; HUE, N.V.; PARRA, A.J. A turbidimetric method for determining phosphate-extractable sulfates in tropical soils. Communications in Soil Science and Plant Analysis, v. 18, p.343-357, 1987.

GILLMAN, G.P. A proposed method or the measurement of exchange properties of highly weathered soils. Australian Journal of Soil Research, v.17, p.129-139, 1979.

GILLMAN, G.P. Effects of $\mathrm{pH}$ and ionic strength on the cation exchange capacity of soils with variable charge. Australian Journal of Soil Research, v.19, p.93-96, 1981.

GILLMAN, G.P.; SUMPTER, E.A. Modification to compulsive exchange method for measuring exchange characteristics of soils. Australian Journal of Soil Research, v.24, p.61-66, 1986.

KILMER, V.J.; ALEXANDER, L.T. Methods of making mechanical analyses of soils. Soil Science, v.68, p.15-24, 1949.

LINDSAY, W.L. Chemical equilibria in soils. New York: John Wiley, 1979. $449 \mathrm{p}$.

LINDSAY, W.L.; NORVELL, W.A. Development of a DTPA soil test for zinc, iron, manganese, and copper. Soil Science Society of America Journal, v.42, p.421-428, 1978.

MALAVOLTA, E.; VITTI, G.C.; OLIVEIRA, S.A. Avaliação do estado nutricional das plantas: princípios e aplicações. 2.ed. Piracicaba: Potafos, 1997. 319p.

RAIJ, B. van; QUAGGIO, J.A.; SILVA, N.M. Extraction of phosphorus, potassium, calcium, and magnesium from soils by an ion-exchange resin procedure. Communications in Soil Science and Plant Analysis, v. 17, p.547-566, 1986.

RHOADES, J.D. Salinity: electrical conductivity and total dissolved solids. In: SPARKS, D.L. (Ed.). Methods of soil analysis: chemical methods. pt.3. Madison: SSSA; ASA, 1996. p.417-435.

SAS INSTITUTE INC. SAS System. Release 8.02. Cary: SAS Institute, 1999.

SONNEVELD, C.; VAN DEN ENDE, J.; DE BES, S.S. Estimating the chemical compositions of soil solutions by obtaining saturation extracts or specific 1:2 by volume extracts. Plant and Soil, v.122, p.169-175, 1990.

WOLT, J.D. Soil solution chemistry: applications to environmental science and agriculture. New York: John Wiley, 1994. 345p.

Received April 30, 2005

Accepted November 04, 2005 